\title{
Evaluation of two-step transformation in Ni-rich titanium-nickel alloys using thermal and internal friction analyses
}

\author{
Fillipe Stephany de Souza Virgolino ${ }^{1}$, Tiago Felipe de Abreu Santos ${ }^{1}$, \\ Carlos Augusto Nascimento Oliveira ${ }^{1}$, Cezar Henrique Gonzalez ${ }^{1}$, \\ Guilherme Gadelha de Sousa ${ }^{1}$, José Mário Carneiro Vilela ${ }^{2}$, \\ Margareth Spangler Andrade ${ }^{2}$
}

\author{
${ }^{1}$ Departament of Mechanical Engineering, Universidade Federal de Pernambuco, Av. da Arquitetura, s/n, CEP: 50740- \\ 550, Recife, Pernambuco, Brasil. \\ ${ }^{2}$ Innovation Institute of Metallurgy and Special Alloys, Centro de Inovação e Tecnologia SENAI FIEMG, Campus \\ CETEC, Belo Horizonte, Minas Gerais, Brasil. \\ e-mail: tiago.felipe@ufpe.br, margareth.andrade@fiemg.com.br
}

\begin{abstract}
The use of Ti-Ni memory alloys covers several fields of application such as medicine, dentistry, actuators, sensors among others. Because of the thermomechanical behavior of these materials, they are an object of continuous studies and their properties are related to the occurrence of thermoelastic martensitic phase transformations. The thermal analyzes were performed using dilatometry and differential scanning calorimetry to determine the temperatures that occurred transformations during the cooling and heating, as well as to evaluate the influence of the thermal treatments performed by dilatometry. The thermomechanical behavior was also evaluated by the internal friction that measured behavior damping considering the structural and microstructural changes. The calorimetry measurements indicated suppression of the $\mathrm{R}$ phase through decomposition of precipitates of $\mathrm{Ti}_{3} \mathrm{~N}_{4}$ after the thermal treatments, that were corroborated by dilatometry and microhardness. This phase was also studied by the technique of internal friction, which showed that the mechanical damping coefficient increased as a function of temperature, due to the movement of the defects induced by tension.
\end{abstract}

Keywords: Ti-Ni, shape-memory effect, internal friction, dilatometry, calorimetry.

\section{INTRODUCTION}

Ti-Ni alloys have important technological applications due to their unique properties of shape-memory and superelasticity [1]. The shape-memory effect (SME) is a thermomechanical phenomenon exhibited by a wide range of alloys, characterized by the ability of these materials to recover their original form following heating, after having undergone apparently permanent alterations [1-3]. Superelasticity is caused by the transformation induced by deformation under load, followed by the reverse transformation [4-5]. Use of these binary alloys is usually limited to applications where temperatures are lower than $100^{\circ} \mathrm{C}$, because the temperature $\left(\mathrm{M}_{\mathrm{S}}\right)$ at which martensitic transformation begins is typically below $60^{\circ} \mathrm{C}$. Alloys with high temperature shape-memory, with $\mathrm{M}_{\mathrm{S}}$ temperatures higher than $100^{\circ} \mathrm{C}$, have been exhaustively studied due to their potential applications in various different areas. Examples are the high temperature ternary alloys TiNiZr and TiNiHf, which were developed with higher $\mathrm{M}_{\mathrm{S}}$ temperatures [6].

Under suitable conditions, the change in shape proceeds by means of the formation and/or rearrangement of martensite needles, induced by the applied stress. During heating, recovery of the original shape occurs by transformation of the martensite to the high temperature phase. The low degree of symmetry of the crystalline structure of martensite, compared to the high temperature phase, results in martensites with different crystallographic orientations reverting to the phase with greater symmetry, which has a smaller number of crystallographic orientations.

The Ti-Ni alloys offer high levels of mechanical damping and can be used in applications requiring the dissipation of energy [7]. Silva et al. [8] used dynamic mechanical analysis (DMA) to show that Ti-Ni alloys have higher damping capacity, compared to stainless steel, aluminum, and brass. At a frequency of 1 $\mathrm{Hz}$, the Ti-Ni alloys provided 10-fold greater damping than the other materials studied. 
In equiatomic Ti-Ni alloys with martensite induced by deformation, the damping capacity of the martensite is related to the movement of the twininter faces. Dislocation scan be introduced by cold working, and their movement contributes to the damping ability of the materials. Hence, the damping capacity of the martensite increases due to the combined effects of the austenite/martensite interfaces and the dislocations [9].

Some Ti-Ni SME alloys are commercially available and researches concerning the SME phenomena intent to adapt their thermo-mechanical properties in the development of applications. As result, the evaluation of their mechanical behavior has brought special importance. Looking at the majority of SME applications, this work is committed to carried out thermomechanical characterization using differential scanning calorimetry to encountered the transformation temperatures during cooling and heating, as well as assess the thermal treatments influences. In addition, damping behavior of R-phase was studied using internal friction technique and transformation temperatures were compared to previous used techniques.

\section{MATERIALS AND METHODS}

The samples used were wires with diameters of $0.50 \mathrm{~mm}$ and $0.76 \mathrm{~mm}$ (obtained from Shape Memory Applications Inc.), here denoted Ti-Ni_01 and Ti-Ni_02, with chemical compositions of Ti-50.2Ni (at.\%). The samples showed SME after reheating at around $500^{\circ} \mathrm{C}$, with $\mathrm{A}_{\mathrm{f}}=37^{\circ} \mathrm{C}$.

\subsection{Thermal treatments and dilatometry tests}

The thermal treatments and the dilatometry assays were performed with an Adamel Lhomargy LK02 instrument, using a temperature range of -150 to $900^{\circ} \mathrm{C}$ and a heating rate of $1^{\circ} \mathrm{C} . \mathrm{s}^{-1}$. In the dilatometer, the samples were stored in liquid nitrogen at a temperature close to $-150^{\circ} \mathrm{C}$, at which the heating was started. The initial length of the samples was $13.12 \mathrm{~mm}$. The dilatometry spectrum was recorded during heating to temperatures of 400 and $900^{\circ} \mathrm{C}$.

The thermal treatments were performed in the dilatometer; at $400{ }^{\circ} \mathrm{C}$ for $30 \mathrm{~min}$ and at $900{ }^{\circ} \mathrm{C}$ for 10 min, and cooling of the chamber was achieved by forced air injection.

\subsection{Microhardness tests}

Before and after the thermal treatments, the samples were submitted to microhardness testing using a load of $100 \mathrm{~g}$ applied for $15 \mathrm{~s}$.

\subsection{Differential scanning calorimetry}

Modulated differential scanning calorimetry (MDSC) assays were performed using a calorimeter (Model 2920, TA Instruments) equipped with a temperature modulation option and a refrigeration system. Two types of tests were used: total and partial cycles. The first considered the entire transformation range, while the second only considered transformation of the $\mathrm{R}$ phase. The total cycle was performed using the temperature range -80 to $80^{\circ} \mathrm{C}$, and the partial cycle used the range 0 to $80^{\circ} \mathrm{C}$. The samples $(\sim 20 \mathrm{mg})$ were placed on copper pans. The heating rate was $2^{\circ} \mathrm{C} \cdot \mathrm{min}^{-1}$ and the temperature modulation was $\pm 2{ }^{\circ} \mathrm{C}$. The modulated DSC temperature mode enabled separation of the signals corresponding to the reversible and irreversible heat fluxes, enabling the characterization of specific features such as the heat capacity of the sample. The transformation temperatures were determined by the tangents method, according to ASTM norms F2004 [10] and F2005 [11], using Universal Analysis 2000 software (TA Instruments).

\subsection{Mechanical relaxation spectroscopy}

Internal friction measurements performed with an inverted torsion pendulum were used to evaluate the $\mathrm{R}$ phase. The other items of equipment utilized were a microcomputer for data acquisition, an HP75000 electromagnetic signal transformer, two ovens (one for radiative heating and one for resistance heating), and an oil bath for tests at low temperatures. Internal friction spectra were obtained at temperatures between -20 and $70{ }^{\circ} \mathrm{C}$, using a heating rate of $10.0^{\circ} \mathrm{C} \cdot \mathrm{min}^{-1}\left(0.17^{\circ} \mathrm{C} . \mathrm{s}^{-1}\right)$. The vibration frequency was around $1 \mathrm{~Hz}$ and the sampling interval was $120 \mathrm{~ms}$. After cooling to ambient temperature, the sample was submitted to a second cycle performed under the same conditions, in order to identify any remaining phenomena.

\section{RESULTS AND DISCUSSION}

Figure 1 shows a DSC curve obtained for the almost as-received Ti-Ni_01sample, using a starting temperature of $80{ }^{\circ} \mathrm{C}$, cooling to $0{ }^{\circ} \mathrm{C}$, and subsequent heating to close to $80^{\circ} \mathrm{C}$. Two transformation scan be seen in this temperature range. During cooling (indicated by the arrow), the $\mathrm{B} 2 \rightarrow \mathrm{R}$ transformation occurred, while 
under heating, the $\mathrm{R}$ phase reverted to austenite. The $\mathrm{R}$ phase can be broadly described as the $\mathrm{B} 2$ phase aligned along one of the diagonals of a cube [5].

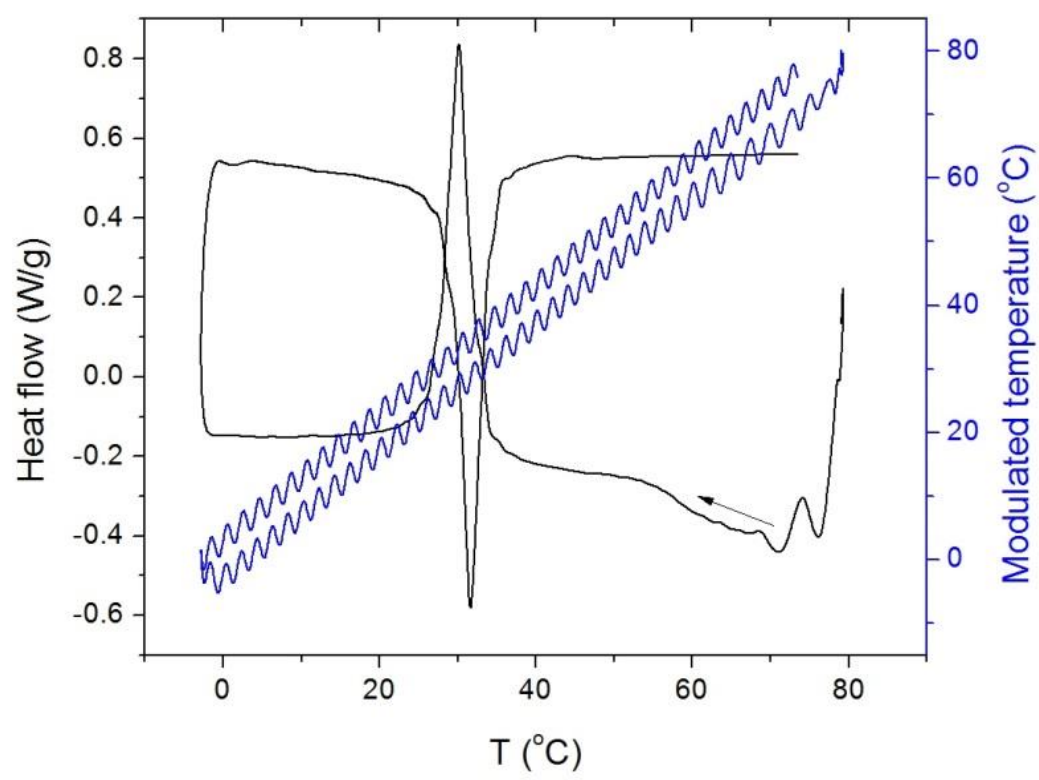

Figure 1: Partial DSC cycle $\left(80^{\circ} \mathrm{C} / 0{ }^{\circ} \mathrm{C} / 80^{\circ} \mathrm{C}\right)$ for the near-equiatomic Ti-Ni_01 sample.

The $\mathrm{B} 2 \rightarrow \mathrm{R}$ and $\mathrm{R} \rightarrow \mathrm{B} 2$ transformation of the Ti-Ni_02 sample during cooling and heating, respectively, in the same temperature range is shown in Figure 2.

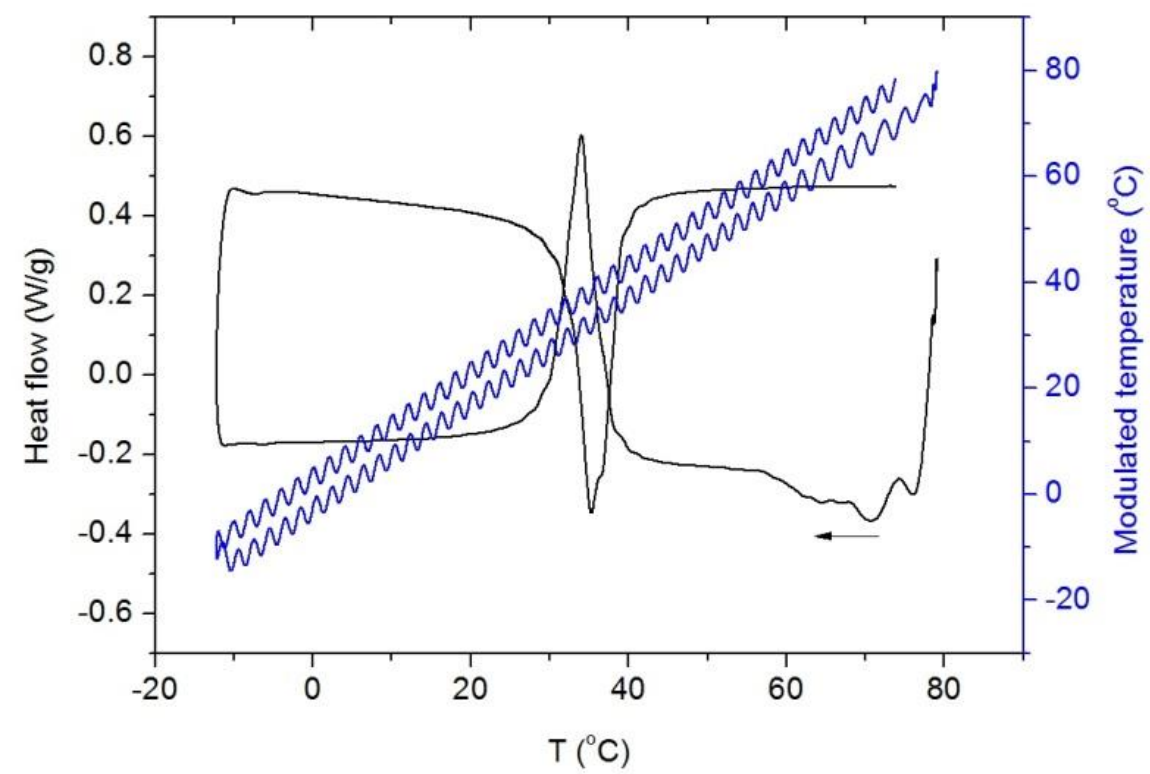

Figure 2: Partial DSC cycle $\left(80^{\circ} \mathrm{C} / 0{ }^{\circ} \mathrm{C} / 80^{\circ} \mathrm{C}\right)$ for the near-equiatomic Ti-Ni_02 sample.

Ti-Ni alloys present high temperature phase (austenite) and low temperature phase (martensite) the austenitic phase of all the Ti-Ni alloys showed a B2 cubic structure (CCC ordered) as pointed out by Otsuka and Ren [5]. The B2 phase can follow different transformation routes, depending on composition and the 
thermomechanical treatment employed. Otsuka \& Ren [5] found that the B2 cubic phase could be transformed to monoclinic B19' martensite, passing through an intermediate rhombohedral or trigonal R phase in the case of aged Ti-Ni-Fe and Ti-Ni alloys, or showing an intermediate orthorhombic B19 phase in the case of Ti-Ni-Cu alloys. According with [5], the appearance of the $\mathrm{R}$ phase is associated with allowing addition and thermomechanical treatments that introduce precipitates and dislocations, altering the transformation temperatures as well as the transformation route and the final product. Additions of $\mathrm{Fe}, \mathrm{Al}$, or $\mathrm{Cu}$ also promote transformation in two stages (B2-R-B19') [5,12]. Some studies [12,13] have indicated Rphase transformation temperatures depends mostly on the $\mathrm{Ni}$ concentration in matrix altered by the presence of $\mathrm{Ti}_{3} \mathrm{Ni}_{4}$ precipitates. Both Fig. 1 and Fig. 2 presented the route B2-R-B2, once the return temperature is high enough to inhibit the B19' martensite.

Figure 3 shows the contributions of the reversible, irreversible, and total heat fluxes. The reversible flux may be associated with changes of heat capacity [14], glass transitions in polymers [13,15] and also phase transition [16,17]. The irreversible heat flux, defined as the difference between the total and reversible heat fluxes, may be related with enthalpic relaxation providing detailed investigation of the phase transformations [15,16]. In specific, Figure 3 shows the partition of reversible and irreversible heat fluxes related to $\mathrm{R} \rightarrow \mathrm{B} 2$ transformation during heating. During the $\mathrm{R}$-phase, the calorific capacity remains constant altering during the transformation down to austenite' calorific capacity as shown by the reversing signal of heat flow (dash curve). Nonreversing signal represents $\mathrm{R} \rightarrow \mathrm{B} 2$ transformation.

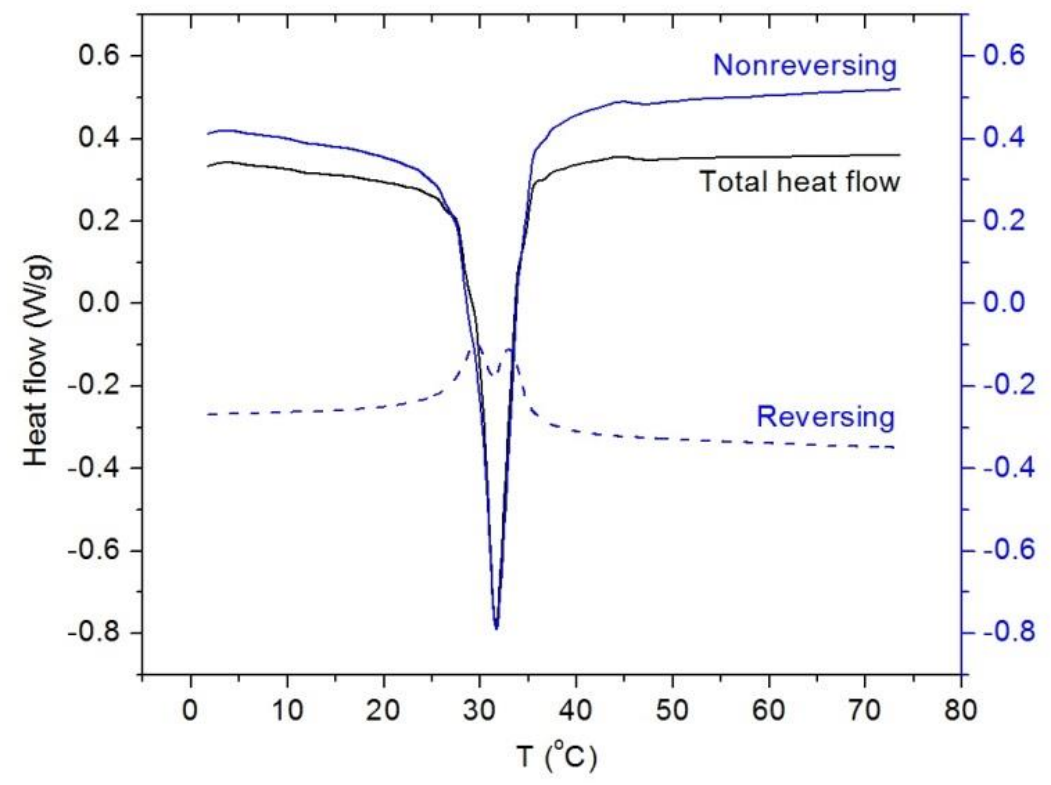

Figure 3: Partial cycle heating of the Ti-Ni_01 sample.

The contributions of the reversible and irreversible heat fluxes can be determined using modulation of the heating ramp. In traditional DSC, a linear temperature ramp enables the heat flux to be obtained as a function of changes in the temperature, mass, and specific heat of the sample. In the case of modulated DSC, a sinusoidal heating rate is applied. In addition to the total heat flux, this enables determination of the contributions of the reversible heat flux (obtained using the ratio between the modulated heat flux and the modulated heating rate) and the irreversible heat flux (calculated as the difference between the total and reversible heat fluxes). One of the advantages of this method is that it enables the discernment of distinct events that reverse in the same temperature range [18]. A modulation of $\pm 2{ }^{\circ} \mathrm{C}$ is shown in Figure 1 and Figure 2, where it can be seen that the sinusoidal ramp remains controlled, even in the regions of phase transformation.

Application of the complete cycle to the Ti-Ni_01 sample resulted in three transformations (Figure 4), namely $B 2 \rightarrow R$, transformation of the $R$ phase to $B 19$ ' martensite $(R \rightarrow B 19$ '), and reversal of the B19'martensite to B2 during heating. The B2-B19' transformation usually occurs in quenched Ti-Ni alloys, while B2-R-B19' occurs in Ti-Ni alloys that are aged or have undergone cold deformation. In addition, the B2-B19-B19' transformation can occur in ternary Ti-Ni-X alloys (where $\mathrm{X}=\mathrm{Cu}, \mathrm{Fe}$, or $\mathrm{Al}$ ). The final 
product of martensitic transformations in Ti-Ni alloys is the monoclinic B19' phase [1,4,5,7,19]. Martensitic transformations govern almost all the properties of SME alloys, including shape memory and superelasticity.

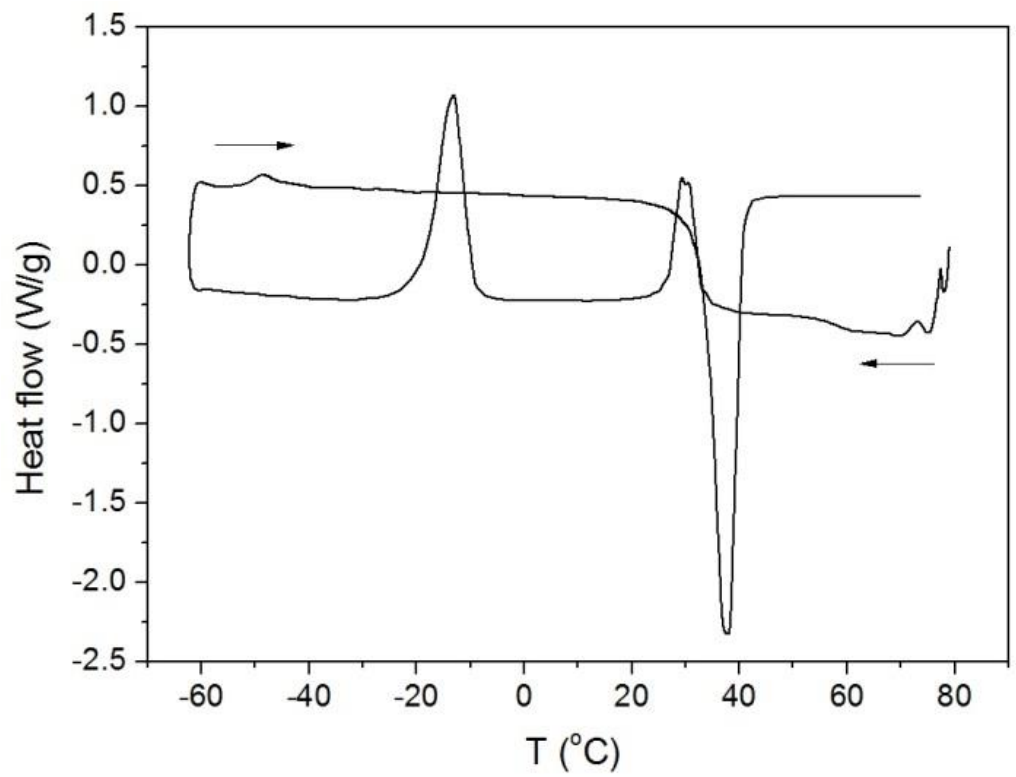

Figure 4: Complete cycle $\left(80{ }^{\circ} \mathrm{C} /-60^{\circ} \mathrm{C} / 80^{\circ} \mathrm{C}\right)$ for the as-received Ti-Ni_01 sample.

Figure 5 shows the complete cycle for the Ti-Ni_02 sample, where the $\mathrm{B} 2 \rightarrow \mathrm{R}$ and $\mathrm{R} \rightarrow \mathrm{B} 19$ ' transformations can be seen during cooling, together with the B19' $\rightarrow \mathrm{B} 2$ transformation in heating. In this transformation $\left(\mathrm{B} 19^{\prime} \rightarrow \mathrm{B} 2\right)$, known as anomalous transformation, where two peaks can be identified during the heating, transformations occur in the region surrounding the grain and then in the interior of the grain [20]. The B19' $\rightarrow \mathrm{B} 2$ reversal started at $22^{\circ} \mathrm{C}$, possibly in the region surrounding the grain (more energetic), and ended at $34^{\circ} \mathrm{C}$, in the interior of the grain [19]. The enthalpy of the first peak during heating was 5.81 $\mathrm{J} / \mathrm{g}$. The transformation temperatures are provided in Table 1 . The enthalpy of the complete transformation $\left(\mathrm{B} 19^{\prime} \rightarrow \mathrm{B} 2\right)$ during heating was $18.96 \mathrm{~J} / \mathrm{g}$, which was very close to the value obtained for the Ti-Ni_01 sample.

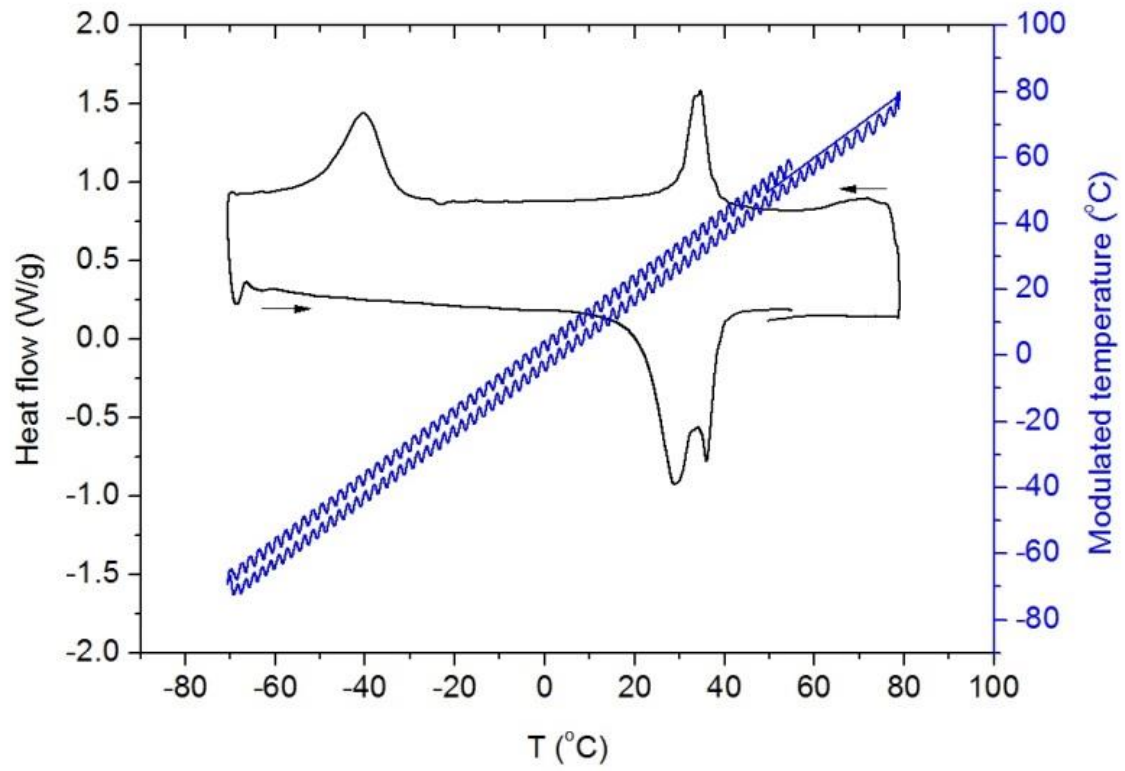

Figure 5: Complete cycle $\left(80^{\circ} \mathrm{C} /-60^{\circ} \mathrm{C} / 80^{\circ} \mathrm{C}\right)$ for the as-received Ti-Ni_02 sample. 
Table 1: Transformation temperatures and enthalpies for the as-received Ti-Ni_01 and Ti-Ni_02 samples, determined using partial and complete DSC cycles.

\begin{tabular}{|c|c|c|c|c|c|c|c|c|c|c|c|c|}
\hline SAMPLE & $\begin{array}{l}R_{\mathbf{s}} \\
\left({ }^{\circ} \mathbf{C}\right)\end{array}$ & $\begin{array}{l}R_{p} \\
\left({ }^{\circ} \mathrm{C}\right)\end{array}$ & $\begin{array}{c}R_{\mathbf{f}} \\
\left({ }^{\circ} \mathrm{C}\right)\end{array}$ & $\begin{array}{l}\Delta \mathrm{H}_{\mathrm{R}} \\
(\mathrm{J} / \mathrm{g})\end{array}$ & $\begin{array}{l}M_{\mathbf{S}} \\
\left({ }^{\circ} \mathrm{C}\right)\end{array}$ & $\begin{array}{l}M_{p} \\
\left({ }^{\circ} \mathrm{C}\right)\end{array}$ & $\begin{array}{l}M_{f} \\
\left({ }^{\circ} \mathrm{C}\right)\end{array}$ & $\begin{array}{l}\Delta \mathrm{H}_{\mathrm{M}} \\
(\mathrm{J} / \mathbf{g})\end{array}$ & $\begin{array}{c}A_{s} \\
\left({ }^{\circ} \mathrm{C}\right)\end{array}$ & $\begin{array}{l}A_{p} \\
\left({ }^{\circ} \mathrm{C}\right)\end{array}$ & $\begin{array}{c}A_{f} \\
\left({ }^{\circ} \mathrm{C}\right)\end{array}$ & $\begin{array}{l}\Delta \mathrm{H}_{\mathrm{A}} \\
(\mathrm{J} / \mathbf{g})\end{array}$ \\
\hline $\begin{array}{c}\text { Ti-Ni_01 } \\
\text { Partial cycle }\end{array}$ & 32 & 30 & 27 & 5.131 & ---- & ---- & ---- & ---- & 29 & 32 & 34 & 5.193 \\
\hline $\begin{array}{c}\text { Ti-Ni_01 } \\
\text { Complete cycle }\end{array}$ & 33 & 29 & 26 & 5.226 & -9 & -13 & -18 & 10.15 & 33 & 38 & 41 & 18.23 \\
\hline $\begin{array}{c}\text { Ti-Ni_02 } \\
\text { Partial cycle }\end{array}$ & 37 & 34 & 30 & 5.939 & ---- & ---- & ---- & ---- & 32 & 35 & 39 & 6.485 \\
\hline $\begin{array}{c}\text { Ti-Ni_02 } \\
\text { Complete cycle }\end{array}$ & 38 & 35 & 30 & 5.725 & -33 & -40 & -49 & 8.624 & 22 & ---- & 39 & 18.96 \\
\hline
\end{tabular}

The magnitude of the enthalpy change associated with martensitic transformation is proportional to the square of the lattice distortion, and therefore depends on the symmetry of the martensite. The heat of transformation decreases with reduced deformation. The lattice distortion of the $\mathrm{R}$ phase was $1 \%$, while values of $8 \%$ and $10 \%$ were obtained for the B19 and B19' phases, respectively. Otsuka \& Ren $[1,4,5]$ concluded that multiple-step martensitic transformation occurs during the course of increasing distortion of the lattice; this provides an explanation for the magnitudes of the enthalpies obtained for the R and B19' phases. Table 1 presents the temperatures and transformation enthalpies for the as-received Ti-Ni samples. It can be seen that the temperature for the start of the $B 2 \rightarrow R$ transformation $\left(R_{s}\right)$, the peak temperature $\left(R_{p}\right)$, and the temperature for the end of the $\mathrm{B} 2 \rightarrow \mathrm{R}$ transformation $\left(\mathrm{R}_{\mathrm{f}}\right)$ were similar, for both the partial and complete cycles, and the same was found for the transformation enthalpy. In the case of the partial cycle, the $\mathrm{R} \rightarrow \mathrm{B} 2$ phase reversal showed similar enthalpies during cooling and heating. On the other hand, in the complete cycle, the transformation enthalpy during heating was much greater, indicating the occurrence of more than one event during the reversal to austenite. When the complete cycle was used for the Ti-Ni_01 sample, the $\mathrm{B} 2 \rightarrow \mathrm{R}$ and $\mathrm{R} \rightarrow \mathrm{B} 19$ 'transformations were observed, with the latter starting at $-9^{\circ} \mathrm{C}$ and ending at $-18^{\circ} \mathrm{C}$. The transformation enthalpy for $\mathrm{R} \rightarrow \mathrm{B} 19^{\prime}$ was approximately $\Delta \mathrm{HR} \rightarrow \mathrm{B} 19^{\prime}=10 \mathrm{~J} / \mathrm{g}$. During heating, the reversal to austenite occurred at higher temperatures when the B19' phase was present, with enthalpy of around $\Delta \mathrm{HA}=18 \mathrm{~J} / \mathrm{g}$. In the case of the Ti-Ni_02 sample, few alterations were observed for R phase transformation, although changes in the transformation temperatures were observed for the B19'martensite. This must be due to the increase of stress fields density promoted by manufacturing process and a possible post heat treatment.

Figure 6 shows the contributions of the reversible and irreversible heat fluxes for the as-received Ti$\mathrm{Ni}$ 01 sample submitted to the complete cycle. The transformations obtained for the irreversible heat flux are also shown in Figure 4. For the irreversible heat flux, the enthalpies of the B2 $\rightarrow R$ and $R \rightarrow B 19$ ' transformations were $6.51 \mathrm{~J} / \mathrm{g}$ and $9.74 \mathrm{~J} / \mathrm{g}$, respectively. During heating, the transformation enthalpy was $17.58 \mathrm{~J} / \mathrm{g}$, which was close to the sum of the individual enthalpies of the R and B19' phases during cooling, indicating the reversal of $\mathrm{B} 19$ '. It is important to note that the irreversible heat flux is directly related to the $1^{\text {st }}$ order transformations, and that modulation enables separation of this signal. For this reason, the enthalpy values for the endothermic and exothermic cycles become closer, due to the separation of phase transformation from other phenomena that could affect the enthalpy. 


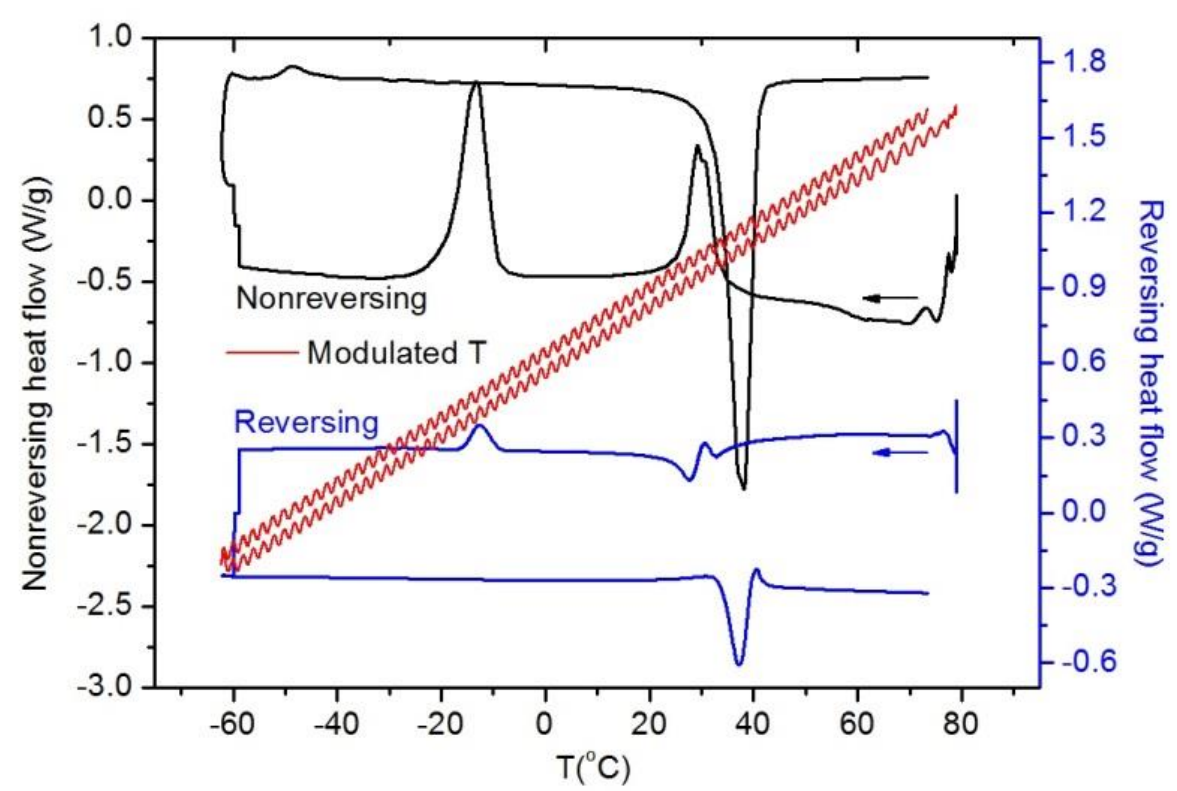

Figure 6: Contributions of reversible and irreversible heat fluxes during the complete cycle $\left(80{ }^{\circ} \mathrm{C} /-60{ }^{\circ} \mathrm{C} / 80{ }^{\circ} \mathrm{C}\right)$ for the as-received Ti-Ni_01 sample.

A convenient way of adjusting the transformation temperatures of nickel-rich Ti-Ni alloys is by means of aging treatment. In the present work, two thermal treatments were used: one at $900{ }^{\circ} \mathrm{C}$ for $10 \mathrm{~min}$, applied to samples Ti-Ni_01 and Ti-Ni_02, and another at $400{ }^{\circ} \mathrm{C}$ for $30 \mathrm{~min}$, applied to sample Ti-Ni_02. The results are described below.

The dilatometry assays (Figure 7 and Figure 8) were performed in two stages. First, the samples were cooled to $-180{ }^{\circ} \mathrm{C}$ with liquid nitrogen, and then heated from $-180^{\circ} \mathrm{C}$ to $60{ }^{\circ} \mathrm{C}$ at a controlled rate. A second sample was heated from ambient temperature to $900{ }^{\circ} \mathrm{C}$, kept at the final temperature for $10 \mathrm{~min}$, and then cooled to near-ambient temperature with helium. Differences in the transformation temperatures obtained during the cooling with liquid nitrogen were due to the lack of control of the cooling rate. During cooling from ambient temperature, two transformations were observed, at around $33{ }^{\circ} \mathrm{C}$ and $-38{ }^{\circ} \mathrm{C}$ (Figure 7), in good agreement with the $\mathrm{B} 2 \rightarrow \mathrm{R}\left(\mathrm{R}_{\mathrm{f}}\right)$ and $\mathrm{R} \rightarrow \mathrm{B} 19^{\prime}\left(\mathrm{M}_{\mathrm{S}}\right)$ transformations, respectively, determined by DSC (Table 1).The temperatures for the beginning $\left(23^{\circ} \mathrm{C}\right)$ and end $\left(42{ }^{\circ} \mathrm{C}\right)$ of the transformation to the $\mathrm{B} 2$ phase (Figure $7 b$ ), $A_{s}$ and $A_{f}$, respectively, corroborated the data obtained from the DSC analyses (Table 1).
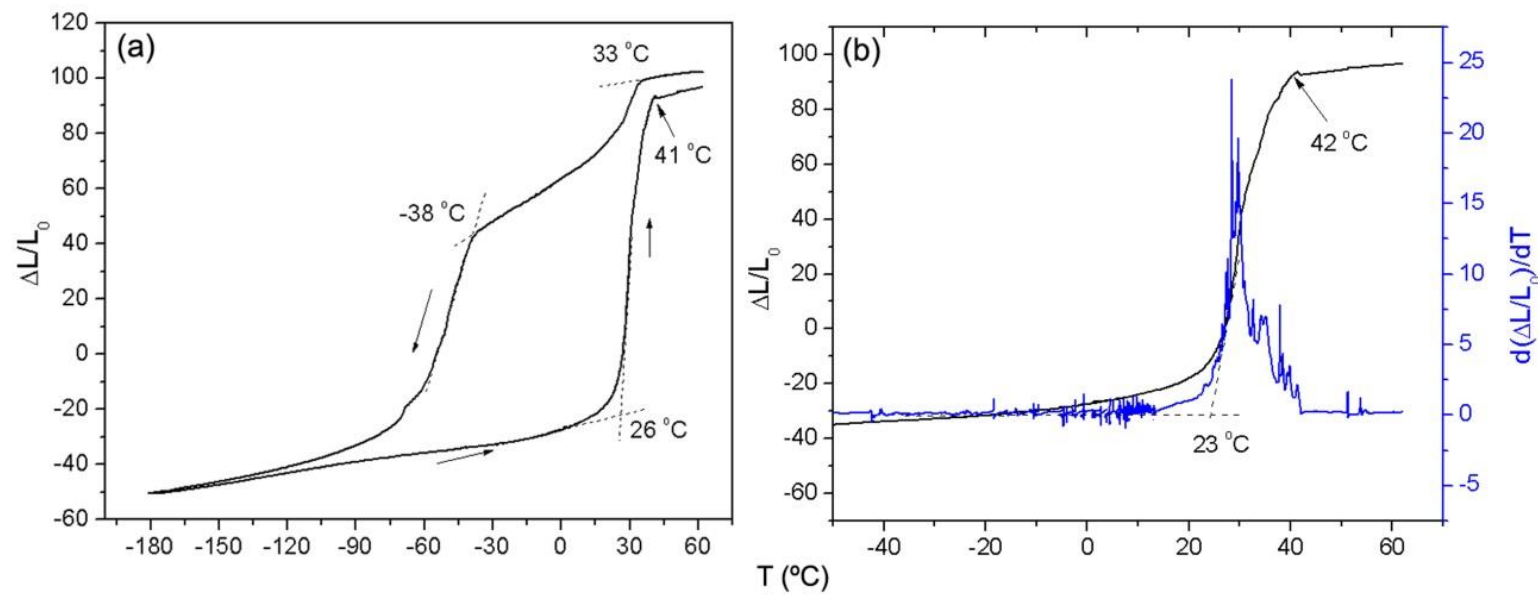

Figure 7: (a) Relative dilatation and (b) its derivative, as a function of temperature in the range from $-180{ }^{\circ} \mathrm{C}$ to $60{ }^{\circ} \mathrm{C}$, for the Ti-Ni_02 sample. 
Figure 8 shows the dilatometry curve obtained during heating of the Ti-Ni_02 sample from ambient temperature to $900{ }^{\circ} \mathrm{C}$, with transformations at around $41^{\circ} \mathrm{C}$ and in the range $443-670{ }^{\circ} \mathrm{C}$. The first of these corresponds to the $\mathrm{A}_{\mathrm{f}}$ for the $\mathrm{B} 19^{\prime} \rightarrow \mathrm{B} 2$ transformation. The volume of the $\mathrm{B} 19^{\prime}$ martensite alteration was appreciably greater than that of the $\mathrm{R} \rightarrow \mathrm{B} 2$ transformation, hence enabling its identification by dilatometry. The transformation at $443-670{ }^{\circ} \mathrm{C}$ was associated with the solubilization of precipitates of Ti3Ni4. During aging, particles of $\mathrm{Ti}_{3} \mathrm{Ni}_{4}$ precipitate in the $\mathrm{B} 2$ matrix, hence reducing the quantity of nickel in the matrix, until an equilibrium state is reached. Otsuka et al. [1] reported a final $\mathrm{Ti}_{3} \mathrm{Ni}_{4}$ dissolution temperature of around $680^{\circ} \mathrm{C}$ for $\mathrm{Ti}-52 \mathrm{Ni}$, Ti-54Ni, and Ti-56Ni alloys, in agreement with the present findings. A possible transformation was apparent at $590{ }^{\circ} \mathrm{C}$ (Figure $8 \mathrm{~b}$ ), which could be attributed to the intermediate product, $\mathrm{Ti}_{2} \mathrm{Ni}_{3}$, which is normally present in the Ti-Ni matrix when a two-stage transformation occurs according with $[21,22]$.
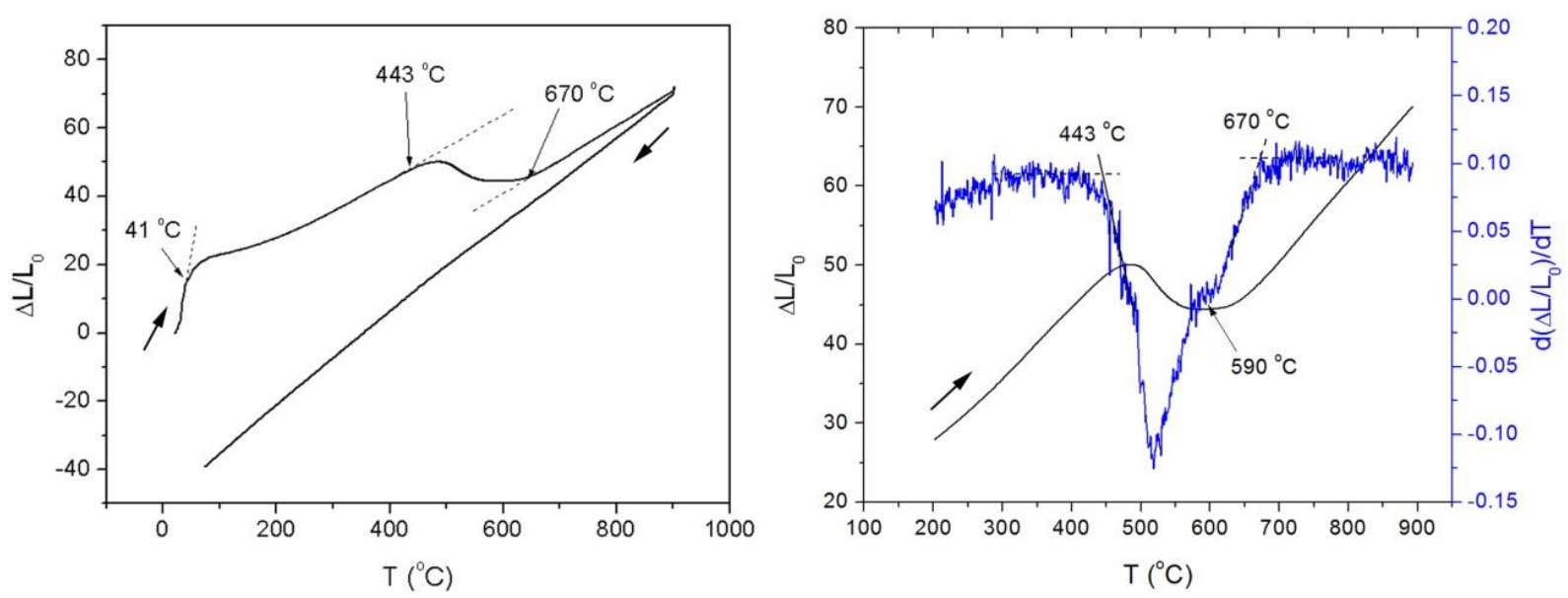

Figure 8: (a) Relative dilatation and (b) its derivative, as a function of temperature in the range from ambient temperature to $900{ }^{\circ} \mathrm{C}$, for the Ti-Ni_02 sample.

Measurements of hardness using microindentation analysis were applied to the as-received samples and the samples that had been treated at $900{ }^{\circ} \mathrm{C}$ for $10 \mathrm{~min}$ in the dilatometer. The results indicated a reduction in hardness from $292 \pm 19 \mathrm{HV}_{0.1 / 15}$ to $194 \pm 15 \mathrm{HV}_{0.1 / 15}$ after treatment. The greater microhardness of the as-received samples was due to the presence of precipitates of $\mathrm{Ti}_{3} \mathrm{Ni}_{4}$. The lower hardness after the thermal treatment was in agreement with the dilatometry data that indicated solubilization of the precipitates as also indicated by Otsuka and Wayman [1]. Precipitates of Ti3Ni4are formed as fine coherent platelets in the matrix during the initial stages of aging at low temperatures, which promotes hardening [1].

The results of the DSC assays performed after thermal treatment of the Ti-Ni_02 sample at $400{ }^{\circ} \mathrm{C}$ for $30 \mathrm{~min}$, and at $900{ }^{\circ} \mathrm{C}$ for $10 \mathrm{~min}$, are shown in Figure 9 and Figure 10, respectively. It can be seen that there was suppression of the $\mathrm{R}$ phase, whose appearance was associated with the presence of the $\mathrm{Ti}_{3} \mathrm{Ni}_{4}$ precipitate. After the thermal treatments, we can see just B2-B19'-B2 route. 


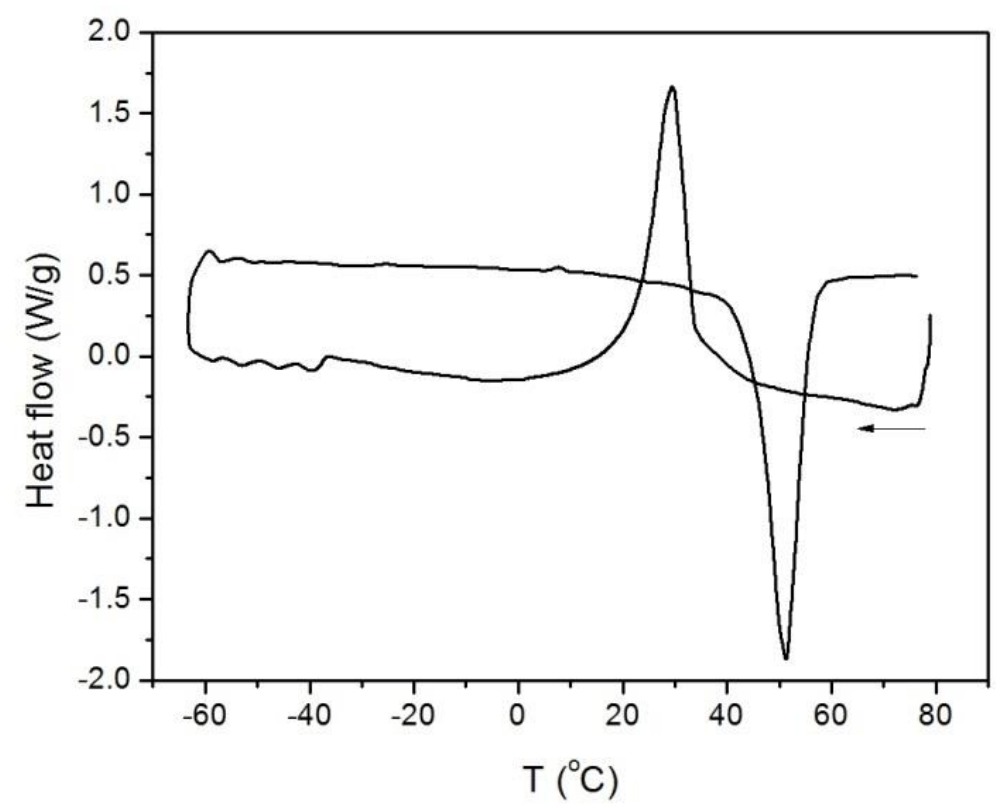

Figure 9: DSC curve for the Ti-Ni_02 sample treated at $400{ }^{\circ} \mathrm{C}$ for $30 \mathrm{~min}$.

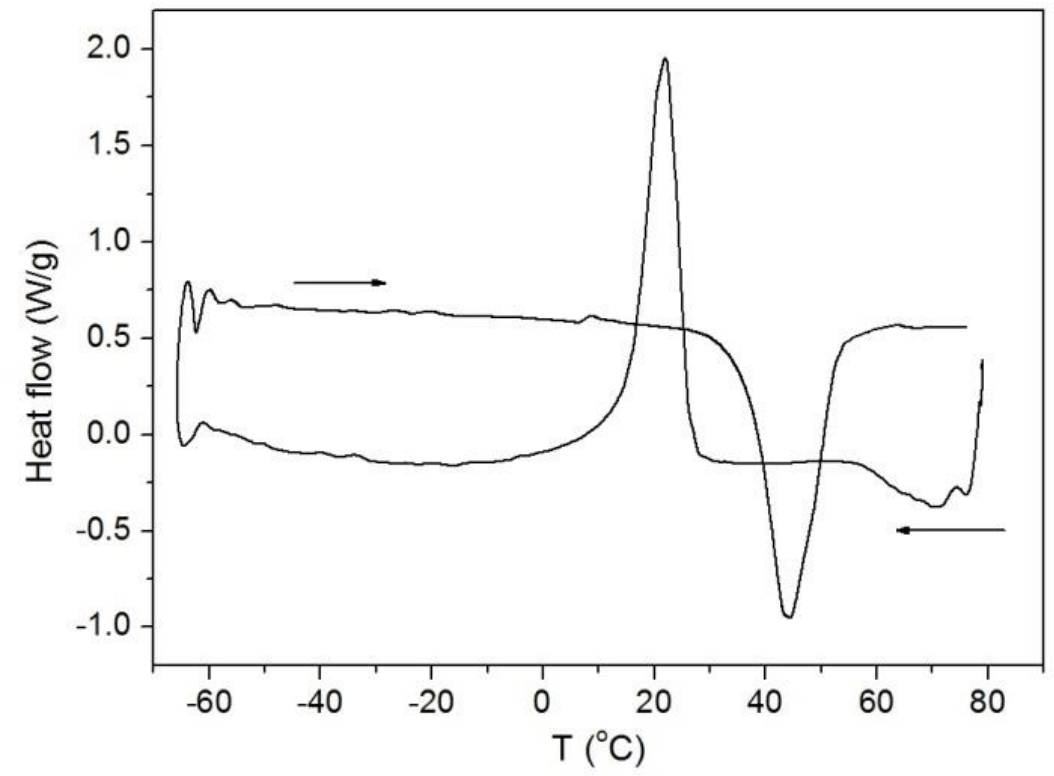

Figure 10: DSC curve for the Ti-Ni_02 sample treated at $900{ }^{\circ} \mathrm{C}$ for $10 \mathrm{~min}$.

The DSC curve obtained for the Ti-Ni_01 sample treated at $900{ }^{\circ} \mathrm{C}$ for $10 \mathrm{~min}$ is shown in Figure 11 , which also evidences suppression of the $\mathrm{R}$ phase. In other work, Bodja et al. [23] used transmission electron microscopy to characterize $\mathrm{Ti}-50.7 \mathrm{Ni}$ samples that had been treated at $850{ }^{\circ} \mathrm{C}$ for $300 \mathrm{~s}$, and reported an absence of $\mathrm{Ti}_{3} \mathrm{Ni}_{4}$ precipitates. 


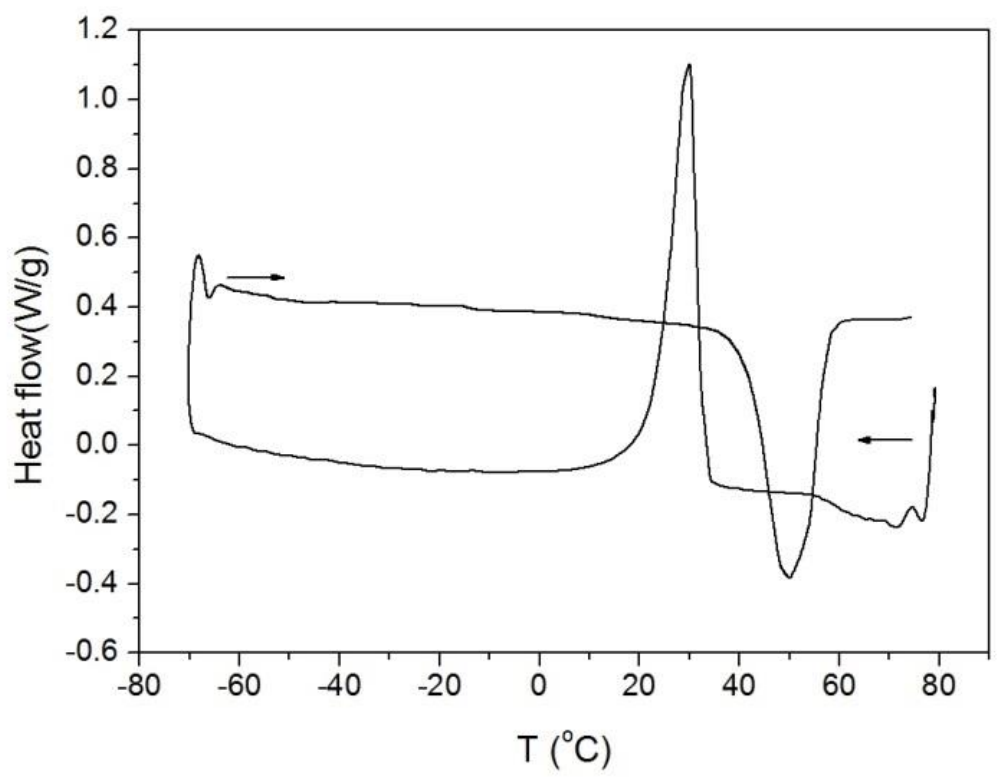

Figure 11: DSC curve for the Ti-Ni_01 sample treated at $900{ }^{\circ} \mathrm{C}$ for $10 \mathrm{~min}$.

Table 2 presents the martensitic transformation temperatures during cooling and heating. Higher $\mathrm{B} 2 \rightarrow \mathrm{B} 19^{\prime}$ transformation temperatures $\left(\mathrm{M}_{\mathrm{S}}\right.$ and $\left.\mathrm{M}_{\mathrm{f}}\right)$ were found for the Ti-Ni_01 sample, relative to the Ti$\mathrm{Ni}$ 02 sample, possible due to difference in manufacturing process and post heat treatment. For the same conditions, it was expected smaller transformation temperatures for Ti-Ni_02 sample. Difference on dissolution of $\mathrm{Ni}$ in the samples also might explain the temperature reduction, because $\mathrm{Ni}$ acts decreasing the transformation temperatures [4,5]. The enthalpy of transformation of the samples treated at $900{ }^{\circ} \mathrm{C}$ indicated formation and reversal of the B19' phase, because the enthalpy was similar for cooling and heating. However, lower transformation temperatures were observed for the Ti-Ni_02 sample. The increase of deformation level implies in higher martensitic transformation temperatures. As result of higher reduction of Ti-Ni_01 samples, the transformation temperatures increased.

Table 2: Transformation temperatures and enthalpies of the Ti-Ni samples after thermal treatment at $400{ }^{\circ} \mathrm{C}$ for $30 \mathrm{~min}$ and $900{ }^{\circ} \mathrm{C}$ for $10 \mathrm{~min}$, determined using DSC.

\begin{tabular}{|c|c|c|c|c|c|c|c|c|c|c|c|c|}
\hline SAMPLES & $\begin{array}{c}\mathbf{R}_{\mathbf{S}} \\
\left({ }^{\circ} \mathrm{C}\right)\end{array}$ & $\begin{array}{c}R_{p} \\
(=\mathrm{C})\end{array}$ & $\begin{array}{c}\mathbf{R}_{\mathbf{f}} \\
\left({ }^{\circ} \mathrm{C}\right)\end{array}$ & $\begin{array}{l}\Delta \mathrm{H}_{\mathrm{R}} \\
(\mathrm{J} / \mathrm{g})\end{array}$ & $\begin{array}{c}M_{S} \\
\left({ }^{\circ}-C\right)\end{array}$ & $\begin{array}{l}M_{p} \\
(-C)\end{array}$ & $\begin{array}{c}M_{\mathbf{f}} \\
\left({ }^{\circ}-C\right)\end{array}$ & $\begin{array}{l}\Delta \mathrm{H}_{\mathrm{M}} \\
(\mathrm{J} / \mathrm{g})\end{array}$ & $\begin{array}{c}A_{s} \\
(\because-C)\end{array}$ & $\begin{array}{c}A_{p} \\
(-C)\end{array}$ & $\begin{array}{c}A_{f} \\
\left({ }^{\circ} C\right)\end{array}$ & $\begin{array}{l}\Delta \mathrm{H}_{\mathrm{A}} \\
(\mathrm{J} / \mathrm{g})\end{array}$ \\
\hline $\begin{array}{c}\text { Ti-Ni_01 } \\
900{ }^{\circ} \mathrm{C}\end{array}$ & ---- & ---- & ---- & ---- & 33 & 30 & 23 & 17.12 & 41 & 50 & 58 & 16.68 \\
\hline $\begin{array}{c}\text { Ti-Ni_02 } \\
900^{\circ} \mathrm{C}\end{array}$ & ---- & ---- & ---- & ---- & 26 & 22 & 15 & 19.62 & 37 & 44 & 53 & 19.45 \\
\hline $\begin{array}{c}\text { Ti-Ni_02 } \\
400^{\circ} \mathrm{C} \\
\end{array}$ & ---- & ---- & ---- & ---- & 34 & 29 & 23 & 18.88 & 45 & 51 & 56 & 21.56 \\
\hline
\end{tabular}

Higher transformation temperatures were found for the samples treated at $400{ }^{\circ} \mathrm{C}$ for $30 \mathrm{~min}$. In terms of transformation energy, different enthalpies were obtained for the endothermic and exothermic cycles. This difference in energy could be explained by the presence of a remaining quantity of the $\mathrm{R}$ phase.

Additional characterization of the $\mathrm{R}$ phase was achieved using internal friction testing (mechanical relaxation spectroscopy), which is a sensitive method of determining damping behavior. Internal friction can be related to the capacity of a material to damp mechanical vibrations, and changes in this capacity are due to microstructural, substructural, or structural alterations [24]. The internal friction was measured as a function of time and temperature, using aKê-type inverted torsion pendulum [25,26]. External factors that influence the internal friction spectrum include the frequency used and thermomechanical phenomena, amongst others. Internal factors include grain size, density of the martensite interface, and structural defects [5].

Figure 12 shows the internal friction spectra for two replicates (A and B) of the Ti-Ni_02 sample submitted to heating and cooling. For both samples, and under both conditions, the coefficient of internal 
friction (or coefficient of dissipation of mechanical energy) was higher at lower temperatures. The samples showed internal friction peaks at around $35{ }^{\circ} \mathrm{C}$ during heating and $30{ }^{\circ} \mathrm{C}$ during cooling. Cai et al. [9] suggested that a higher damping coefficient for the $\mathrm{R}$ phase is related to the presence of martensite interfaces. Chang et al. [27] attributed high friction coefficients obtained for the R and B19' phases to movement of the twin boundaries. Collizi et al. [28] also suggested that twin movements induced by stress were responsible for increased internal friction in Ti-Ni alloys. Internal friction in the austenitic phase is due to reversible movement of the dislocations and defect points, and is of lower intensity than for the martensitic phase, where the internal friction is related to the martensite/austenite interfaces and the twin boundaries. The oscillation frequency of a sample shows a minimum for the region of peak internal friction, as found here for all the samples and conditions. The oscillation frequency during cooling of sample B is shown in Figure 12. A new heating and cooling cycle was performed for the Ti-Ni_02 sample (Figure 13), showing the reversibility of the $\mathrm{B} 2 \rightarrow \mathrm{R}$ and $\mathrm{R} \rightarrow \mathrm{B} 2$ transformations.

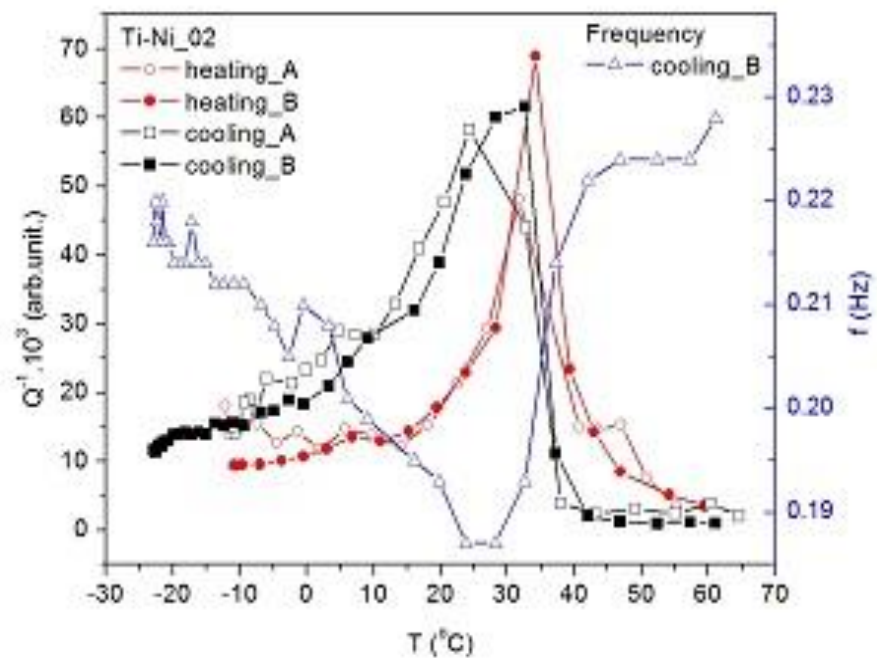

Figure 12: Internal friction spectra for the Ti-Ni_02 sample (replicates A and B).

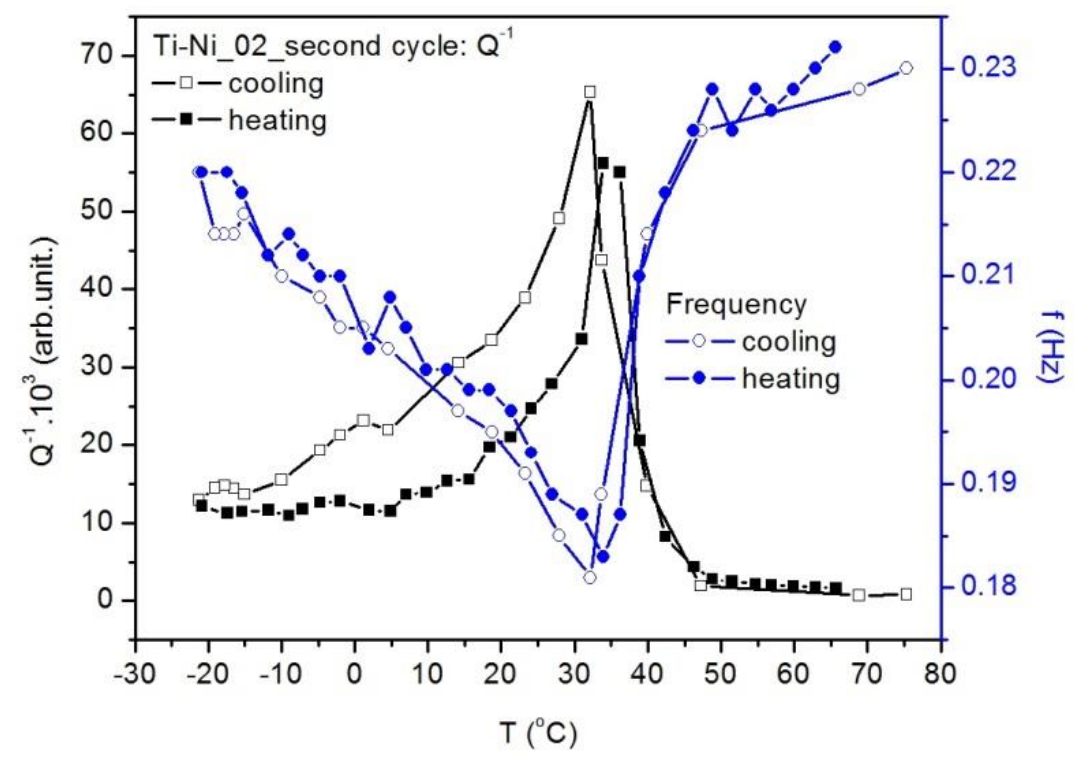

Figure 13: Internal friction curves and torsion pendulum oscillation frequencies for the Ti-Ni_02 sample submitted to the second cycle. 
The temperatures at which the friction coefficient changes can be related to the transformation temperatures. Table 3 gives these temperatures for the as-received samples submitted to two cycles. Although some of the temperatures were not determined by the internal friction technique, for those that were determined, agreement was found between the first and second cycles, indicating the reversibility of the $\mathrm{R}$ phase. In addition, the data were in agreement with the results of the DSC and dilatometry analyses (Table 1, Figure 7). $R_{\mathrm{S}}$ temperature transformation during cooling measured during $1^{\text {st }}$ cycle of internal friction was 38 ${ }^{\circ} \mathrm{C}$, such as described in dilatometry $\left(\mathrm{B} 2 \rightarrow \mathrm{R}\left(\mathrm{R}_{\mathrm{f}}\right), 33^{\circ} \mathrm{C}\right)$ and calorimetry measurements for both samples (32 ${ }^{\circ} \mathrm{C}$, sample $01 ; 38^{\circ} \mathrm{C}$, sample 02 ). During heating, dilatometry measurements (Fig. $7 \mathrm{~b}$ ) have shown martensite to austenite temperatures transformation of $26^{\circ} \mathrm{C}$ and $42^{\circ} \mathrm{C}$, which are presented in the $1^{\text {st }}$ cycle of internal friction (in heating) as $\mathrm{A}_{\mathrm{S}}\left(23^{\circ} \mathrm{C}\right)$ and $\mathrm{A}_{\mathrm{f}}\left(42^{\circ} \mathrm{C}\right)$, the initial and final martensite to austenite temperatures transformations, respectively. In DSC, these temperatures were $22^{\circ} \mathrm{C}$ and $39^{\circ} \mathrm{C}$ for complete cycle, Ti-Ni_02 sample (Table 1).

Table 3: Direct and reverse $\mathrm{R}$ phase transformation temperatures obtained using internal friction measurements.

\begin{tabular}{|c|c|c|c|c|c|c|}
\hline SAMPLE & $\mathbf{R}_{\mathbf{s}}\left({ }^{\circ} \mathbf{C}\right)$ & $\mathbf{R}_{\mathbf{p}}\left({ }^{\circ} \mathbf{C}\right)$ & $\mathbf{R}_{\mathbf{f}}\left({ }^{\circ} \mathbf{C}\right)$ & $\mathbf{A}_{\mathbf{s}}\left({ }^{\circ} \mathbf{C}\right)$ & $\mathbf{A}_{\mathbf{p}}\left({ }^{\circ} \mathbf{C}\right)$ & $\mathbf{A}_{\mathbf{f}}\left({ }^{\circ} \mathbf{C}\right)$ \\
\hline 1st cycle & 38 & 30 & ---- & 23 & 34 & 42 \\
\hline 2nd cycle & ---- & 32 & 41 & ---- & 35 & 41 \\
\hline
\end{tabular}

\section{CONCLUSIONS}

Two Ti-Ni samples were analyzed using differential scanning calorimetry that pointed out lower transformation temperatures for the minor diameter that was submitted to more reduction during manufacturing steps. This behavior was observed during partial and complete calorimetry cycle. On the other hand, lower deformation during manufacturing steps, large diameters, provided higher transformation temperatures.

The partial cycle allow to see the austenite to R-phase and the reversal transformation. When, a complete cycle was performed, the austenite transforms into R-phase and R-phase to martensite. The modulation was implemented to separate connected events, although it is not possible to see different phenomena, the modulation allow to measure more accuracy the transformations enthalpies of the studied events.

The decomposition of $\mathrm{Ti}_{3} \mathrm{Ni}_{4}$ precipitates, which promoted intermediate transformation involving the $\mathrm{R}$ phase, was indicated by dilatometric and microhardness analyses, in agreement with the calorimetry results. DSC analyses indicated suppression of the $\mathrm{R}$ phase after the thermal treatments performed using a dilatometer, revealing that the B2-B19' transformation occurred directly.

Use of the internal friction technique, used to study reversal of the $\mathrm{R}$ phase, revealed that the mechanical damping coefficient increased as a function of temperature, due to movement of the defects induced by tension. The temperatures transformation of R-phase was in agreement of previous measurements performed by DSC and dilatometry.

\section{ACKNOWLEDGMENTS}

The authors are grateful for the support provided by CNPq, CAPES and FAPEMIG. TFAS thanks Institute Senai Fiemg (Cetec campus), FACEPE and UFPE.

\section{BIBLIOGRAPHY}

[1] OTSUKA, K., WAYMAN, C.M., Shape memory materials, 1 ed., Cambridge university press, 1999.

[2] DELAEY, L., KRISHNAN, R. V., TAS, H., et al., (1974). Thermoelasticity, pseudoelasticity and the memory effects associated with martensitic transformations. Journal of Materials Science, v. 9, n. 9, pp. 1521-1535, 1974.

[3] ANDRADE, M.S., SILVA, J.E., LARA, M.H.S., "Estudo de ligas Ti-Ni e Cu-Zn-Al com efeito memória de forma”, In: Congresso CBECIMAT 8, Campinas, São Paulo, Brazil, 1988.

[4] OTSUKA, K., REN, X. "Recent developments in the research of shape memory alloys", Intermetallics, v. 
7, n. 5, pp. 511-528, 1999.

[5] OTSUKA, K., REN, X. "Physical metallurgy of Ti-Ni-based shape memory alloys", Progress in materials science, v. 50, n. 5, pp. 511-678, 2005.

[6] HSIEH, S. F.; WU, S. K. "Damping characteristics of a Ti40. 5Ni49. 5Zr10 shape memory alloy". Journal of alloys and compounds, v. 403, n. 1-2, pp. 154-160, 2005.

[7] ANDRADE, M. S., SILVA, E. M. "Características Estruturais e Mecânicas de uma Liga de TiNi no Intervalo 20-100 ${ }^{\circ}$ ", In: $35^{\circ}$ Congresso Anual da Associação Brasileira de Metalurgia e Materiais Metalurgia $A B M$, São Paulo, v. 276, pp. 719-722, 1980.

[8] SILVA, N. J., ARAÚJO, C., GONZALEZ, C. H., et al., "Estudo comparativo das propriedades dinâmicas de uma liga NiTi com memória de forma e materiais estruturais clássicos". Matéria, v. 16, pp. 830-835, 2011.

[9] CAI, W., LU, X. L., ZHAO, L. C. "Damping behavior of TiNi-based shape memory alloys", Materials Science and Engineering: A, v. 394, n. 1-2, pp. 78-82, 2005.

[10] ASTM F2004-05. Standard Test Method for Transformation Temperature of Nickel-Titanium Alloys by Thermal Analysis. West Conshohocken: ASTM International, 2010.

[11] ASTM F2005-05. Standard Terminology for Nickel-Titanium Shape Memory Alloys. West Conshohocken: ASTM International, 2010.

[12] WANG X.B., B. VERLINDEN, H. J. V. "R-phase transformation in NiTi alloy", Materials Science and Technology, v.30, n. 13, pp. 1517-1529, Jan. 2014.

[13] WANG, X., VERLINDEN, B., VAN, H. "Effect of post-deformation annealing on the R-phase transformation temperatures in NiTi shape memory alloys", Intermetallics, v. 62, pp. 43-49, Jan 2015.

[14] GILL, P. S., SAUERBRUNN, S. R., READING, M. "Modulated differential scanning calorimetry", Journal of Thermal Analysis, v. 40, n. 3, pp. 931-939, 1993.

[15] JONES K.J., I. KINSHOTT, READING, M., et al., "Temperature Modulated Calorimetry", Thermochim Acta, v. 304, pp. 187-199, November, 1997.

[16] BRANTLEY, W. A., IIJIMA, M., GRENTZER, T. H. "Temperature-modulated DSC study of phase transformations in nickel-titanium orthodontic wires", Thermochimica Acta, v. 392, pp. 329-337, 2002.

[17] BRANTLEY, W. A., IIJIMA, M., GRENTZER, T. H. "Temperature-modulated DSC provides new insight about nickel-titanium wire transformations", American journal of orthodontics and dentofacial orthopedics, v. 124, n. 4, pp. 387-394, 2003.

[18] THOMAS, L. C. "An introduction to the techniques of differential scanning calorimetry (DSC) and modulated DSC", In: Thermal Analysis. Fundamentals and Applications to Material Characterization. R. Artiaga (ed.). Publicationes de la Universidade da Coruna, Coruna, 2005, 9-25.

[19] PINA, E.A.C., ARAÚJO, O.O. FILHO, OLIVEIRA, C.A.N., et al., "Caracterização de fios de TiNi com efeito memória deforma viabilizando fabricação de molas helicoidais" In: VI Congresso Nacional de Engenharia Mecânica (CONEM), Campina Grande, 2010.

[20] WANG, Z. G., ZU, X. T. "Incomplete transformation induced multiple-step transformation in TiNi shape memory alloys". Scripta materialia, v. 53, n. 3, pp. 335-339, 2005.

[21] FAN, G.,Y. ZHOU, W. C., YANG, S., et al., "Precipitation kinetics of Ti3Ni4 in polycrystalline Ni-rich TiNi alloys and its relation to abnormal multistage transformation behavior", Materials Science and Engineering: A, v. 438-440, pp. 622-626. November, 2006.

[22] PAULA, A.S., CANEJO, J.P.H.G., MARTINS, R.M.S., et al., "Effect of thermal cycling on the transformation temperature ranges of a Ni-Ti shape memory alloy", Materials Science and Engineering: A, v. 378, n. 1-2, pp. 92-96. July, 2004.

[23] BOJDA, O., EGGELER, G., DLOUHÝ, A. "Precipitation of Ni4Ti3-variants in a polycrystalline Ni-rich NiTi shape memory alloy", Scripta materialia, v. 53, n. 1, pp. 99-104, 2005.

[24] NOWICK, A.S., BERRY, B.S. Anelastic Relaxation in Crystalline Solids. Characterization of Anelastic Behavior, 1 ed., New York: Academic Press, 1972.

[25] KÊ, T.'ING-SUI. "Experimental evidence of the viscous behavior of grain boundaries in metals", Physical Review, v. 71, pp.533-546. 1946

[26] SANTOS, T.F.A., ANDRADE, M.S.“Internal Friction on AISI 304 Stainless Steels with Low Tensile 
Deformations at Temperatures between -50 and 20 ${ }^{\circ}$ ", Adv. Mater. Sci. Eng., v. 2010, pp. 1-9. July, 2010.

[27] CHANG, S. H., WU, S. K. "Inherent internal friction of B2 $\rightarrow$ R and R $\rightarrow$ B19' martensitic transformations in equiatomic TiNi shape memory alloy", Scripta materialia, v. 55, n. 4, pp. 311-314, 2006.

[28] COLUZZI B., BISCARINI A., CAMPANELLA R., et al., "Mechanical spectroscopy and twin boundary properties in a Ni-50.8Ti-49.2 alloy", Acta materialia, v.47, n. 6, pp. 1965-1976. April, 1999.

\section{ORCID}

Fillipe Stephany de Souza Virgolino Tiago Felipe de Abreu Santos

Carlos Augusto Nascimento Oliveira

Cezar Henrique Gonzalez

Guilherme Gadelha de Sousa

José Mário Carneiro Vilela

Margareth Spangler Andrade https://orcid.org/0000-0003-3273-4095

https://orcid.org/0000-0003-2273-0760

https://orcid.org/0000-0003-1122-1610

https://orcid.org/0000-0001-9317-3143

https://orcid.org/0000-0002-8906-5737

https://orcid.org/0000-0002-0157-6058

https://orcid.org/0000-0002-2937-5012 